\title{
INVESTIGATING DRIVERS OF CHOICE BEHAVIOR: \\ CORPORATE IMAGE, PERCEIVED RISK AND TRUST INTERACTIONS THROUGH REPUTATION MANAGEMENT
}

\author{
Huseyin KANIBIR \\ EPOKA University, Albania \\ Sima NART \\ Balikesir University, Turkey
}

\begin{abstract}
This study examines how reputation management (RM) activities influence consumers' choice behaviors. In order to understand the relationship between them the possible consequences of RM activities such as corporate image, consumer trust, and perceived risk were analyzed as the antecedents of consumers' choice behavior. Specifically, a structural equation model was developed for hypothesized relations between the constructs of the study. An empirical research was conducted by using data from 232 individual consumers in Albania $(n=109)$ and Turkey $(n=123)$ to test our conceptual model. The data were analyzed through $t$ test and structural equation modelling (SEM). The study shows that RM activities obviously determine the constructs of corporate image and consumer trust positively, whereas the perceived risk by consumers negatively. The lower level of perceived risk through RM activities was found as a significant determinant of consumers' choice behavior.
\end{abstract}

Keywords: Reputation management, choice behavior, consumer trust, image

\section{INTRODUCTION}

In marketing science, psychological processes behind consumer behaviors and preferences are accepted as key determinant based on vast body of research on their reactions to products, brands and the names of the firms. This understanding prescribes that general beliefs about a firm can determine the way in which consumers make their decisions toward the given firm. Also, marketing research mentions that the factor of consumer trust is another important key determinant in decision making process (Moorman et al., 1992; Chen and Tan, 2004). Both factors are the leading parts of psychological process although objective evaluations such as firm performance and quality of offerings are significant in arising of these two factors. If market players can manage succesfully the psychological processes of consumers, then they can able to increase the possibility to be chosen by consumers among many other competitors. This viewpoint builds a practical question for firms: what strategies and activities increase positively consumers' beliefs and trust toward the firm? This study examines reputation management activities from a perspective of increasing positive image of any firm and consumer trust to create choice behavior in favor of the firm.

Reputation has been defined as the intangible asset expressing the evaluation of target market on whether the firm is substantially 'good' or 'bad' (Weiss et al. 1999), and reflects the cumulative knowledge about the past and present acts of the organisation (Suh and 
Amine, 2007). In today's highly competitive markets, reputation is not a result that is appeared by itself, and that can be gained by chance. However, it is an organizational value that could be improved by management perspective with the long term strategies. Shortly, creating a good reputation for a firm requires the understanding of strategic marketing management to transform these activities into reputation management.

Reputation gained by successful strategic marketing management can be demolished in very short run if the attention is not sustainable. Although reputation is an abstract concept, it has a potential to generate concrete values if it is created successfully by any firm. Fombrun (1996) states the meaning of positive reputation perceived by consumers for an organization in terms of competitive advantages as follows: (1) delaying rival mobility in the industry, (2) charging price premium on customers, at least in highly uncertain markets, (3) attracting higher-quality and larger amounts of investments from the stock market, (4) maintaining a high spirit among employees, (5) supporting and enhancing new product introduction and recovery strategies in the event of a crisis (Fombrun \& Shanley, 1990; Fombrun, 1996).

However, although there is extensive research on reputation management (Weigelt and Camerer, 1988; Fombrun, 1996; Roberts and Dowling, 2002; Cretu and Brodie, 2007) the literature stil suffers from a lack of empirical studies that examine whether reputation management activities shift perceived risk by consumers through creating positive corporate image in the minds of consumers and establishing consumer trust. Therefore, the aim of this study is to explore the relationship between reputation management activities and consumers' choice behaviors through perceived corporate image, consumer trust, and perceived risk by consumers exposing to reputation management activities of firms. The knowledge this study generates is expected to contribute to the competitiveness topic of marketing literature by its research model considering the consequences of reputation management activities as the antecedents of choice behavior.

The rest of the paper is organized as follows: First, literature review is presented to recognize the main variables of the study. Second, we present a research model indicating the hypothesized relationships between constructs. Finally, methodology of the research, data analysis and findings will be presented, followed by a conclusion with the limitations of this research study.

\section{LITERATURE REVIEW AND DEVELOPMENT OF HYPOTHESES}

\section{Reputation Management}

Intensive competition, the most leading feature of today's markets, forces market players to find various strategic advantages. A widely accepted theory of the resource-based view of the firm (Barney, 1991) points out that valuable, rare, inimitable, and nonsubstitutable resources of the firms are essential for stronger and long-term competitiveness. It should be noted that the resources building competitiveness are not related only to production and technical processes such as $\mathrm{R} \& \mathrm{D}$, efficiency, cost, but also related to managing the general psychology in the marketplace towards the firm. When consumers have negative associations for a firm then market performance of the firm probably will not be independent from them. In other words, what consumers, competitors, and related institutions of the market are saying about the firm is a directly part of market performance since the words have an obvious power to attract and discourage individuals into a given market player. Thus, reputation of any firm can play as rare, inimitable, and nonsubstitutable resource in a highly competitive market environment to encourage consumers toward the firm if it can be built successfully. Reputation of a firm, therefore, can be considered to be a psychological antecedent in consumer decision-making process. It is possible to consider this dimension as a leading strategic resource for competitive advantage of any firm (Fombrun, 1996; Capozzi, 2005). In this context, the concepts of reputation, reputation management (RM), and reputation management (RM) activities attract attention particularly from the management and marketing areas examining the question of how to be competitive (i.e., Roberts and Dowling, 1997; Hutton et al., 2001; Capozzi, 2005; Cretu and Brodie, 2007). Reputation is ocurred around individuality, what a person or an organization is known for. In business literature, it is therefore defined as an overall evaluation of the extent to which a firm is substantially "good or bad", or "positive or negative" (Deephouse, 2000; Roberts \& Dowling, 2002). The reputation occured for a firm in the marketplace can include real, perceived and incorrect dimensions. Even if it is sometimes incorrect or unreal, reputation of a firm has a power to influence consumers' reactions. There is a consensus among academicians on corporate reputation that must be purposefully managed rather than driving by chance so that it can contribute to the competitiveness of the firm ( Fombrun, 1996; Formbrun and van Riel, 2004; 
Simoes et al., 2005). Thus, designing specific activities to manage the process of building reputation comes into prominence from strategic behavior.

\section{Corporate Image}

Corporate image is described as the overall impression made on the minds of individuals about an organization (Finn, 1961; Kotler, 1982; Dichter, 1985; Barich and Kotler, 1991). In marketing literature, image is defined as a mental construct processed internally (Crompton, 1979), or as a mental picture of consumers (Dobni and Zinkhan, 1990) for any given offering such as business name, variety of products, package design and quality, appearance of store.

Some empirical evidence in marketing field clearly show that long-term reputation of the seller has been found to be more important than short-term product quality movements (Landon \& Smith, 1997). McKnight et al., (1998) report, based on empirical research, that corporate reputation provides assurance of consumers' integrity and goodwill. Assurance also help to increase trust, particularly when the consumers have not experience before and hence do not have first hand knowledge for the firm. A typicall example provides a valuable insight for this relation: there is a perceive notion around the world that products processed in China will not have long-life due to not meeting quality standards. Products from China maybe really unquality or low-quality and it is normally expected that consumers experienced these products before will avoid new transactions, but it is not uncommon to observe consumers avoiding made-inChina products who have not experience with them before. It is possible to explain this type of consumer behavior with poor reputation of China in marketplace. Poor reputation results in poor image in the minds of consumers.

It is, therefore, expected that the more positively consumers think about a firm, the more positively their perceptions towards the corporate image. In line with the foundation built above, the following hypothesis is proposed:

H1: There is a positive relationship between RM activities and corporate image.

\section{Trust}

From the view of social exchange theory (Blau, 1964; Cook and Emerson, 1978) trust is a leading factor in a relation between consumers and the firm. The theory emphasizes the importance of human psychology in forming social exchanges. Research prove that the lack of trust can directly disrupt to get a relationship on from consumer side. Thus, trust can be described as a psychological antedecent for consumer behavior (Garbarino and Johnson, 1999; Ba and Pavlou, 2002; Pavlou and Gefen, 2004).

Serving to the creation of positive reputation for the firm through specific and pre-planned activities, and managing the corporate image can increase the value of the intangible assets such as trust (Calantone, Cavusgil \& Zhao, 2002). Positive reputation of the firm and brilliant corporate image are expected to function as a preceding state for trust in consumer psychology, based on social exchange theory. Several research (Weigelt \& Camerer, 1988; Garbarino \& Johnson, 1999; Plank, Reid, \& Pullins, 1999) report that corporate reputation has a vital role in reducing the uncertainty consumers encounter when they evaluate firms. Positive corporate reputation is based on superior performance over a certain period of time. In other words, positive corporate reputation can lead creating confidence, and thus increasing the trust (Morgan \& Hunt, 1994). Based on the above reasoning we propose that:

H2: There is a positive relationship between RM activities and consumer trust.

H3: There is a positive relationship between corporate image and consumer trust.

\section{Perceived Risk}

The factor of risk perceived by consumers has been a foremost question in marketing discipline (Murray and Schlacter, 1990; Dowling and Staeling, 1994; Mitchell, 1999) since it has been considered to be a leading part of human psychology in decision-making process. Risk is defined as an individual's or a group's perceptions of the uncertainty for engaging in an activity (Dowling and Staelin, 1994). Bauer (1960) stated this "the uncertain consequences resulting from purchase". From this perspective, risk perceptions of consumers arise from potentially negative results of any engagement. Some academicians (Engel, Blackwell, and Miniard (1986, p. 109) consider perceived risk as "beliefs about the risks associated with product (service) purchase". In marketing literature there is a widely accepted classification based on the study of Jacoby and Kaplan (1972) that includes financial, physical, psychological, performance, and social risk. Greatoresk and Mitchell (1994) identified social risk as "social loss", and added the sixth category as time risk.

Trust and percived risk are closely interrelated (Mayer et al., 1995). In terms of managerial perspective, consumer trust and positive corporate image leads to more positive perceptions towards the quality of the 
products, and the firm as a whole. Marketing literature, based on a vast body of empirical evidence, suggests that the mentioned constructs encourage consumers by cutting negative associations about the firm (McKnight et al., 1998; Garbarino and Johnson, 1999; Pavlou and Gefen, 2004; Cretu \& Brodie, 2007). In other words, the level of perceived risk can be decreased by increasing the positive clues.

The higher the perceptions of risk, the higher the trust needed to facilitate a transaction. When risk is present, higher level of trust is needed to make transactions possible. That is, consumer trust toward a product or an organization reduces the perceived risk for a specific offering. As a result, the firms attached to positive associations are expected to behave well and avoid negative behaviors, which strengthen customers' perceptions towards lower level perceived risk. Based on this view we hypothesize that:

H4: There is a negative relationship between corporate image and perceived risk by consumers.

H5: There is a negative relationship between consumer trust and perceived risk by consumers.

\section{Choice Behavior}

Understanding the essential determinants in the process of the evaluation of consumers behavior has been a supreme aim in the field of marketing. It is possible to state that customers' evaluations towards a product, a brand or the name of the organization are signals of actual choice behavior (Zeithaml, Berry and Parasuraman,1996), based on structural psychology (George ve Jones, 1999, p.532) in which human behaviors are described as the activity done consciously. This description also emphasizes the important difference between "behavior" and "motion". The underlying indication from the discipline of psychology emphasizing the connection between behavior and its antecedents explains specifically that most human behavior is under volitional control (Ryan, 1970). There are different ways of examining choice behavior of consumers in marketing literature. For example, Bloemer and Odekerken-Schröder (2007) examines price insensitivity in the context of choice behavior. Bansal, Irving, and Taylor (2004) investigate consumers' choice behaviors in the context of switching intentions. On the other hand, Mittal, Kumar, and Tsiros (1999) measure customers' intention to recommend to other people, which can be considered to be an indicator of choice behavior if it is positive.

Consumers' choice behaviors among competing offerings emerge based on maximazing their benefits as it is implied in the explanations from psychology area (Becker, 1990; Tversky and Kahneman, 1981). Lower level of risk perceived by consumers is a direct part of higher benefits. In other words, reducing risk ensures consumers to reach more satisfactory results. A rational theory of consumer behavior (Tversky and Kahneman, 1986, 1991) imply that consumers will employ the level of risk they perceive as a cue for their possible satisfaction. From this perspective, perceived risk by consumers is a main indicator in terms of whether they engage in a brand or a firm. In short, the more risk consumers perceive the less choice behavior they exhibit. More specifically, if they perceive relatively higher level of risk towards a firm, then they are more likely to have the intension not to prefer, switching intensions, negative word-of-mouth and price sensitivity. Based on this view we hypothesize that:

H6: There is a negative relationship between perceived risk and choice behavior of onsumers.

Building on the literature review and the hypotheses developed, the following model emerged as the research model of this study (figure 1). In the research model, five main constructs and the relations between them are examined through hypothesized paths.

Fig. 1. Conceptual model and hypothesized relations

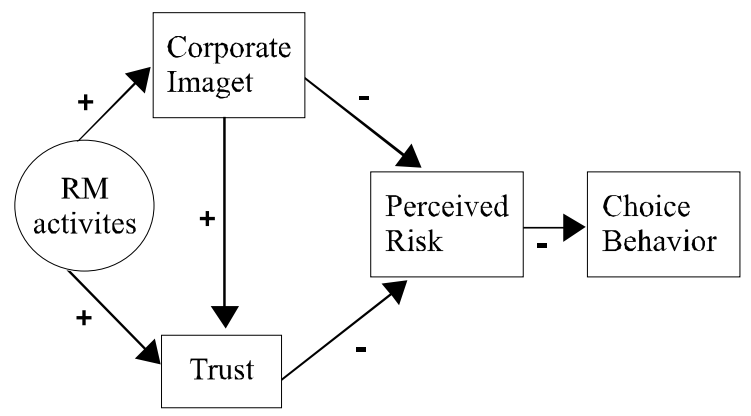

\section{RESEARCH DESIGN}

The research in this study was conducted by employing a quantitative methodology. In this context, a structured questionnaire was developed as data collection instrument based on literature review and previous research (e.g., Sirdeshmukh et al., 2002; Selnes and Sallis, 2003; Dowling, 2006). The sample for this survey consisted of customers who were staying at Sheraton Hotels in Tirana, Albania and Istanbul, Turkey, in the period of February - April 2009. The survey was limited to only businessmen segment due to their constant demand for hotel services, and thus their enhanced familiarity. The design of the questionnaire was based on 5 different constructs examined in this research. As presented in table 1, 2, 
3,4 and 5 , reputation management (RM) activities were measured using the scale adopted from Fombrun (1998) and Fombrun, Gardberg, and Sever (2000). Items for measuring consumer trust were adopted from Selnes and Sallis (2003). The construct of corporate image was adopted from the study of $\mathrm{Wu}$ and Petroshius (1987). For the variable of perceived risk, we employed the well-known definition of Engel, Blackwell, and Miniard (1986, p. 109) and wellestablished classification of Jacoby and Kaplan (1972) for perceived risk by consumers. And finally, choice behavior was measured using items from Bansal et al., 2004; Mittal et al., 1999; Zeithaml et al., 1996).

All constructs were measured on five-point Likert scales ranging from Definitely agree to Definitely disagree. The overall value of the Cronbach alpha to assess the reliability of the variables was 0.83 , indicating a satisfactory level.

\section{Descriptive Statistics}

In total, 268 usable questionnaires were collected from participants over the course of three months (February - April 2009) in Albania and Turkey simultaneously. Of those gathered thirty-six forms were eliminated $(13.4 \%)$ due to excessive amount of missing data. Thus, 232 forms of data were coded for data analysis.
The distribution of questionnaires analysed by country is as follows: Respondents from Albania were 109 (47\%) and from Turkey were 123 (53\%) of the overall sample. The analysis of demographic characteristics of the sample revealed that most of them were male (169 respondents; $73 \%$ ) and in the 45 - 60 year age category (171 respondents; $73.7 \%$ ). Just above half had a university degree (131 respondents; $56.4 \%$ ).

\section{DATA ANALYSIS AND RESULTS}

\section{Analysis of Differences between Albanian and Turkish Consumers}

In the first step of the analysis, the collected data were analyzed by employing the SPSS program. A series of independent $t$ - tests were used to determine if differences existed between Albanian and Turkish consumers across the constructs of the research model. Table 1 indicates the differences between the subgroups of the sample in the evaluation of RM activities.

Note: The negative t-values mean that Turkish respondents have higher mean scores than Albanian respondents for the related items. The criteria were based on a five-point scale, ranging from " 1 = Definitely agree" to " $5=$ definitely disagree".

Table 1: Mean Differences between Albanian and Turkish Consumers for RM Activities

\begin{tabular}{|c|c|c|c|c|}
\hline statements & $\mathbf{A L}$ & TR & t - value & Sig. \\
\hline Average & 4.46 & 4.80 & -1.83 & 0.068 \\
\hline Declaring to provide high quality offerings every time & 4.22 & 4.61 & -1.81 & 0.071 \\
\hline Declaring to provide value-for-money offerings every time & 4.32 & 4.55 & -1.36 & 0.173 \\
\hline Declaring to provide new and innovative offerings every time & 3.96 & 4.67 & -2.61 & 0.015 \\
\hline $\begin{array}{l}\text { Declaring that the philosophy shared by all staff is high } \\
\text { customer satisfaction }\end{array}$ & 4.43 & 4.38 & 1.81 & 0.071 \\
\hline Showing its upper-class level through comments on media & 4.51 & 4.77 & -1.62 & 0.103 \\
\hline Announcing the names of famous guests staying at Sheraton & 4.46 & 4.71 & -2.47 & 0.022 \\
\hline Employing upper-class marketing channells & 4.49 & 4.40 & 0.56 & .510 \\
\hline $\begin{array}{l}\text { Creating a feeling of first-class company through specific } \\
\text { advertisements }\end{array}$ & 4.24 & 4.65 & -2.59 & 0.011 \\
\hline Designing an extraordinary building in external view & 4.79 & 4.61 & 0.810 & 0.412 \\
\hline Designing exclusive atmosphere inside the hotel & 4.88 & 4.29 & 3.26 & 0.003 \\
\hline Providing excellent working environment to its staff & 4.63 & 4.51 & 1.87 & 0.062 \\
\hline Equiping its staff with superior qualifications & 4.70 & 4.27 & 2.27 & 0.025 \\
\hline Building high standards in human relations & 4.83 & 4.52 & 1.75 & 0.078 \\
\hline Hosting and sponsoring eminent art events & 4.80 & 4.66 & 1.82 & 0.070 \\
\hline $\begin{array}{l}\text { Hosting many popular meetings (official meetings, } \\
\text { popular weddings, cocktail parties) }\end{array}$ & 4.21 & 4.79 & -2.51 & 0.014 \\
\hline Supporting and announcing many societal projects & 3.91 & 4.48 & -2.38 & 0.017 \\
\hline Declaring its environmental responsibility and sensitivity & 4.27 & 4.49 & -1.77 & 0.075 \\
\hline
\end{tabular}


The findings of the comparison between Albanian and Turkish groups showed that Turkish consumers had a slightly higher. But this finding cannot be confirmed by statistical results ( $\mathrm{p}>0.05)$. Based on the results in table A, no significant difference was found for the evaluation of RM activities. Although Turkish consumers have higher scores, Albanian consumers also have very positive overall evaluations towards the firm's RM activities. It should be noted that the largest difference was found in the "designing exclusive atmosphere inside the hotel" ( $\mathrm{p}<0.01$ ), indicating one of the lowest scores from Turkish group as 4.29 that means very positive. This means that both groups in different countries have similarly positive perceptions for RM activities of the firm.

While analyzing the relationships among the constructs across the research model, the second construct is determined as corporate image. Table 2 reports the view of the corporate image from the respondents' evaluations.

Table 2: Mean Differences between Albanian and Turkish Consumers for Corporate Image

\begin{tabular}{|l|r|rr|r|}
\hline \multicolumn{1}{|c|}{ average } & AL & TR & $\begin{array}{r}\mathbf{t} \text { - } \\
\text { value }\end{array}$ & Sig. \\
\hline Has a pleasant atmosphere & 4.62 & 4.41 & 1.74 & 0.078 \\
\hline a well-known brand & 4.90 & 4.77 & 1.60 & 0.073 \\
\hline $\begin{array}{l}\text { Has high quality goods } \\
\text { and services }\end{array}$ & 4.82 & 4.33 & 0.104 \\
\hline Well-managed firm & 4.41 & 4.44 & -0.67 & 0.498 \\
\hline Has polite staff & 4.33 & 4.68 & -1.72 & 0.081 \\
\hline $\begin{array}{l}\text { Has consumer- } \\
\text { oriented staff }\end{array}$ & 4.22 & 4.31 & -0.86 & 0.397 \\
\hline $\begin{array}{l}\text { Attracts upper-class } \\
\text { customers }\end{array}$ & 4.76 & 4.28 & 2.10 & 0.036 \\
\hline Means prestigious & 4.60 & 4.12 & 1.99 & 0.039 \\
\hline Exclusive firm & 4.88 & 4.36 & 2.14 & 0.033 \\
\hline
\end{tabular}

Note: The negative t-values mean that Turkish respondents have higher mean scores than Albanian respondents for the related items. The criteria were based on a five-point scale, ranging from " 1 = Definitely agree" to "5= definitely disagree".

Table 2 shows that there is no significant difference between Albanian and Turkish consumers for the evaluations towards CI of the firm. Both groups are seen to have very positive assessments. In comparison with those of Albanian consumers, Turkish consumers had slightly lower scores but not confirmed statistically $(p>0.05)$. Similarly, in both groups the most positive evaluation was reported on the item the firm is a wellknown brand (mean scores: 4.90 and 4.77, respectively). For Albanian group, clearly it is possible to see the reflections of CI since they ranked the item it is an exclusive firm as second highest (4.88). Also in Turkish group, it should be noted that overall scores for CI items are above 4.00. The largest difference existed between the groups on the firm has high quality goods and services which means that the former had much more positive views than the latter $(p<0.05)$. However, the mean value of Turkish group for this item can also be considered rather positive (4.33). The data obtained from the sample of this study in two different countries clearly prove a brilliant CI for the firm in the minds of respondents.

Table 3: Mean Differences between Albanian and Turkish Consumers for Trust*

\begin{tabular}{|l|r|r|r|r|}
\hline \multicolumn{1}{|c|}{ average } & 4.59 & 4.42 & 1.73 & 0.081 \\
\hline & & & & \\
\hline $\begin{array}{l}\text { I trust that S is } \\
\text { competent at what they } \\
\text { are doing }\end{array}$ & 4.89 & 4.41 & 1.81 & 0.070 \\
\hline $\begin{array}{l}\text { I feel that S is } \\
\text { trustworthy. }\end{array}$ & 4.81 & 4.13 & 3.31 & 0.001 \\
\hline $\begin{array}{l}\text { I feel that S is honest to } \\
\text { fulfill its promises }\end{array}$ & 4.70 & 4.19 & 2.12 & 0.034 \\
\hline $\begin{array}{l}\text { I think that S is very } \\
\text { responsive to customers. }\end{array}$ & 4.33 & 4.68 & -1.77 & 0.076 \\
\hline $\begin{array}{l}\text { I believe that S will } \\
\text { respond with } \\
\text { understanding in } \\
\text { the event of problems }\end{array}$ & 4.22 & 4.72 & -1.87 & 0.064 \\
\hline
\end{tabular}

* Note: The negative t-values mean that Turkish respondents have higher mean scores than Albanian respondents for the related items. The criteria were based on a five-point scale, ranging from

"1= Definitely agree" to "5= definitely disagree".

R: Reverse coded.

The findings of the comparison between Albanian and Turkish consumers for the dimension of trust are presented in Table 3. Based on average scores come from the subgroups of the sample, a statistically significant difference was not reported by significance level ( $p>0.05$ ) for t-value computed (1.73). Respondents both in Albania and Turkey seem similar to each other in terms of trust towards Sheraton (grand mean values: 4.59 and 4.42 , respectively). The largest difference between the groups was observed for item I feel that Sheraton is trustworthy which means 
Table 4: Mean Differences between Albanian and Turkish Consumers for Perceived Risk*

\begin{tabular}{|l|r|r|r|r|}
\hline & AL & TR & $\begin{array}{r}\text { t- } \\
\text { value }\end{array}$ & Sig. \\
\hline average & $\mathbf{4 . 4 0}$ & $\mathbf{4 . 6 5}$ & $-\mathbf{1 . 8 2}$ & 0.068 \\
\hline $\begin{array}{l}\text { In S, Facing offerings that } \\
\text { are not value-for-money is } \\
\text { a serious risk. (R) }\end{array}$ & 4.32 & 4.60 & -1.91 & 0.063 \\
\hline $\begin{array}{l}\text { Satisfactoriness of physical } \\
\text { environment in S is } \\
\text { a serious risk. (R) }\end{array}$ & 4.45 & 4.62 & -1.94 & 0.062 \\
\hline $\begin{array}{l}\text { It is a serious risk that the } \\
\text { goods and services offered } \\
\text { by S can be inadequate in } \\
\text { order to meet my needs (R) }\end{array}$ & 4.12 & 4.71 & -2.31 & $\mathbf{0 . 0 2 4}$ \\
\hline $\begin{array}{l}\text { Staying at S can create } \\
\text { unhappiness in my inner } \\
\text { world (R) }\end{array}$ & 4.76 & 4.81 & -1.35 & 0.177 \\
\hline $\begin{array}{l}\text { If I say to friends that I } \\
\text { prefer S, they may } \\
\text { condemn me (R) }\end{array}$ & 4.38 & 4.53 & -1.79 & 0.071 \\
\hline
\end{tabular}

Table 5: Mean Differences between Albanian and Turkish Consumers for Choice Behavior*

\begin{tabular}{|l|r|r|r|r|}
\hline & AL & TR & $\begin{array}{r}\text { t- } \\
\text { value }\end{array}$ & Sig. \\
\hline average & $\mathbf{4 . 2 5}$ & $\mathbf{4 . 1 2}$ & $\mathbf{1 . 5 7}$ & \\
\hline I will prefer S in the future. & 4.13 & 4.05 & 1.80 & 0.073 \\
\hline $\begin{array}{l}\text { I will consider S the first } \\
\text { choice at which to stay. }\end{array}$ & 4.58 & 4.37 & 1.93 & 0.058 \\
\hline $\begin{array}{l}\text { I don't think that the other } \\
\text { brands will provide clearly } \\
\text { better offerings. }\end{array}$ & 4.11 & 4.07 & 1.86 & 0.062 \\
\hline $\begin{array}{l}\text { It is a low possibility that } \\
\text { I will shift S with a } \\
\text { competitive one. }\end{array}$ & 4.18 & 3.99 & 1.74 & 0.081 \\
\hline
\end{tabular}

Albanian respondents clearly much more positive attitudes in favor of Sheraton than the respondents in Turkey (mean values: 4.81 and 4.13 , respectively). Based on the grand mean values, it is possible to state that the sample as a whole clearly has the feeling of trust towards the firm.

Table 4 provides the results of perceived risk by respondents towards the firm, Sheraton. The results reveal that there were no significant differences between the mean scores except one item on risk for inadequacy of offerings to meet individual needs $((\mathrm{p}$ $<0.05$ ). It is important to note that this part of the scale measuring perceived risk towards the firm was established with 5 reverse coded items. The negative signs of the $t$-values indicate less perceived risk by Turkish respondents than Albanians. However, the mean scores of Albanians can be considered as a strong indicator that they perceive risk at minimum level towards the firm. Likewise the grand mean scores for both 2 groups report the similarity statistically (tvalue: -1.82 and $p>0.05$ ). This result shows that the respondents both in Albania and Turkey are sure about the standards of the firm, and thus they do not worry about the firm and its offerings.

Table 5 summarizes the data obtained from the sample on their choice behavior. According to the results shown in table 5, overall the items were assessed similarly by Albanian and Turkish respondents. These four items all have a probability value that is more than .05. Grand mean scores for both groups $(4.25$ and 4.12 , respectively) did not produce statistically significant difference ( $\mathrm{t}$-value: 1.57 and $\mathrm{p}>0.05$ ). The mean scores ranged from 4.11 to 4.58 in the group of Albanians, and from 3.99 to 4.37 in Turkish group, indicating a strong loyalty or very positive choice intention in the future. These findings indicate that respondents preferred the firm, Sheraton, consciously at present, and clearly they have a tendency to keep this behavior on.

The overall analyses of responses through $5 \mathrm{t}$-test operations point out the obvious resemblance between Albanian and Turkish respondents towards the given stimuli. It should be noted that those stimuli are the main constructs within the research model of this study. It is possible, therefore, to put together the subgroups of the sample while analyzing the research model rather than conducting separate analyses.

\section{Analysis of the Research Model}

This study was designed to understand the effects of the factor of reputation management which target market considers when they prefer a brand or a firm rather than its competitors. In this study, a structured model related to the variables assumed to be influential on choice behavior of consumers was tested by employing the Structural Equation Modeling (SEM). The structure, composed of the relationship of 4 assumed constructs to one main dependent variable (choice behavior) constitutes the model of the study to be tested. As mentioned before, the reliability coefficient of the overall scale was computed as Cronbach alpha ; 0.83. Data analysis involves evaluation of the measurement model and the structural model. 


\section{The Evaluation of the Overall Model}

For the overall model, the Chi-square value was found significant as 514.93 with 233 degrees of freedom. This value is not unusual for larger sizes of sample (Doney and Cannon, 1997). The ratio of Chi-square to degree of freedom is 2.21 , which is adequate statistically for the fit of the model. Although the values of GFI (0.93) and AGFI (0.92) are lower than those of CFI (0.97), NFI (0.93) and NNFI (0.94), it is accepted that CFI values above 0.95 are suggestive of a meaningful model (Hu and Bentler, 1999). The fit indices calculated here with RMSEA (0.058) and SRMSR (0.073) can be considered as adequate. All related indices were summarized in Table 6 .

Table 6: Goodness-of-fit summary

\begin{tabular}{|l|c|}
\hline Fit indices & Values \\
\hline $\mathrm{X}^{2}$ & 514.93 \\
\hline Ratio $\left(\mathrm{X}^{2} / \mathrm{df}\right)$ & 2.21 \\
\hline GFI & .93 \\
\hline AGFI & .92 \\
\hline NFI & .93 \\
\hline NNFI & .94 \\
\hline CFI & .97 \\
\hline Standardized RMSR & .07 \\
\hline RMSEA & .06 \\
\hline
\end{tabular}

GFI, Goodness of fit index; AGFI, Adjusted Goodness of fit index; NFI, Bentler-Bonett normed fit index;
NNFI, Bentler-Bonett non-normed fit index; CFI, comparative fit index; RMSR, root mean squared residual, RMSEA, root mean squarred error of approximation.

\section{Measurement Model}

The quality of the model was assessed on unidimensionality, convergent validity, reliability and discriminant validity (see Table 7). The unidimensionality of each construct in the model was analyzed with principal component analysis that reveals the appropriate items loaded at least 0.60 on the hypothesized components. A good overall model fit has provided support for convergent validity of the scale through all loadings that were significant $(\mathrm{p}<$ 0.05 ). Many of the R2 values have exceeded 0.50 proposed by Fornell and Larcker (1981). On the other hand, reliability of the measurement model was analyzed based on the values of composite reliability that should be greater than the benchmark of 0.70 to be considered adequate (Fornell and Larcker, 1981). As indicated in table 7, all the reliability values are above 0.70 , revealing adequate reliability.

Discriminant validity was tested by confirmatory factor model in which correlations between constructs were constrained to 1 , Chi-square differences were significant throughout the model $(p<0.01)$. The model of the study, therefore, is proper to be applied for understanding the relationships between the constructs given with the support of reliability, convergent validity, discriminant validity and unidimensionality.

Table 7: Measurement Model

\begin{tabular}{|c|c|c|c|c|c|}
\hline & & $\begin{array}{l}\text { Composite } \\
\text { reliability }\end{array}$ & $\begin{array}{r}\text { Variance } \\
\text { Explained }\end{array}$ & Loading & $\mathbf{R}^{2}$ \\
\hline \multirow{2}{*}{$\begin{array}{l}\text { Reputation } \\
\text { Management Activities } \\
\text { ( Fombrun, 1998; }\end{array}$} & $\begin{array}{l}\text { 1. Declaring to provide high quality } \\
\text { offerings every time }\end{array}$ & 0.77 & 0.72 & 0.88 & 0.74 \\
\hline & $\begin{array}{l}\text { 2. Declaring to provide } \\
\text { value-for-money offerings every time }\end{array}$ & & & 0.81 & 0.63 \\
\hline \multirow[t]{8}{*}{$\begin{array}{l}\text { Fombrun, Gardberg, } \\
\text { and Sever ,2000) }\end{array}$} & $\begin{array}{l}\text { 3. Declaring to provide new and } \\
\text { innovative offerings every time }\end{array}$ & & & 0.76 & 0.55 \\
\hline & $\begin{array}{l}\text { 4. Declaring that the philosophy shared } \\
\text { by all staff is high customer satisfaction }\end{array}$ & & & 0.89 & 0.74 \\
\hline & $\begin{array}{l}\text { 5. Showing its upper-class level } \\
\text { through comments on media }\end{array}$ & & & 0.72 & 0.52 \\
\hline & $\begin{array}{l}\text { 6. Announcing the names of famous } \\
\text { guests staying at } S\end{array}$ & & & 0.67 & 0.48 \\
\hline & $\begin{array}{l}\text { 7. Employing upper-class marketing } \\
\text { channels }\end{array}$ & & & 0.63 & 0.42 \\
\hline & $\begin{array}{l}\text { 8. Creating a feeling of first-class } \\
\text { company through specific adverti sements }\end{array}$ & & & 0.92 & 0.79 \\
\hline & $\begin{array}{l}\text { 9. Designing an extraordinary } \\
\text { building in external view }\end{array}$ & & & 0.76 & 0.55 \\
\hline & $\begin{array}{l}\text { 10. Designing exclusive atmosphere } \\
\text { inside the hotel }\end{array}$ & & & 0.91 & 0.79 \\
\hline
\end{tabular}




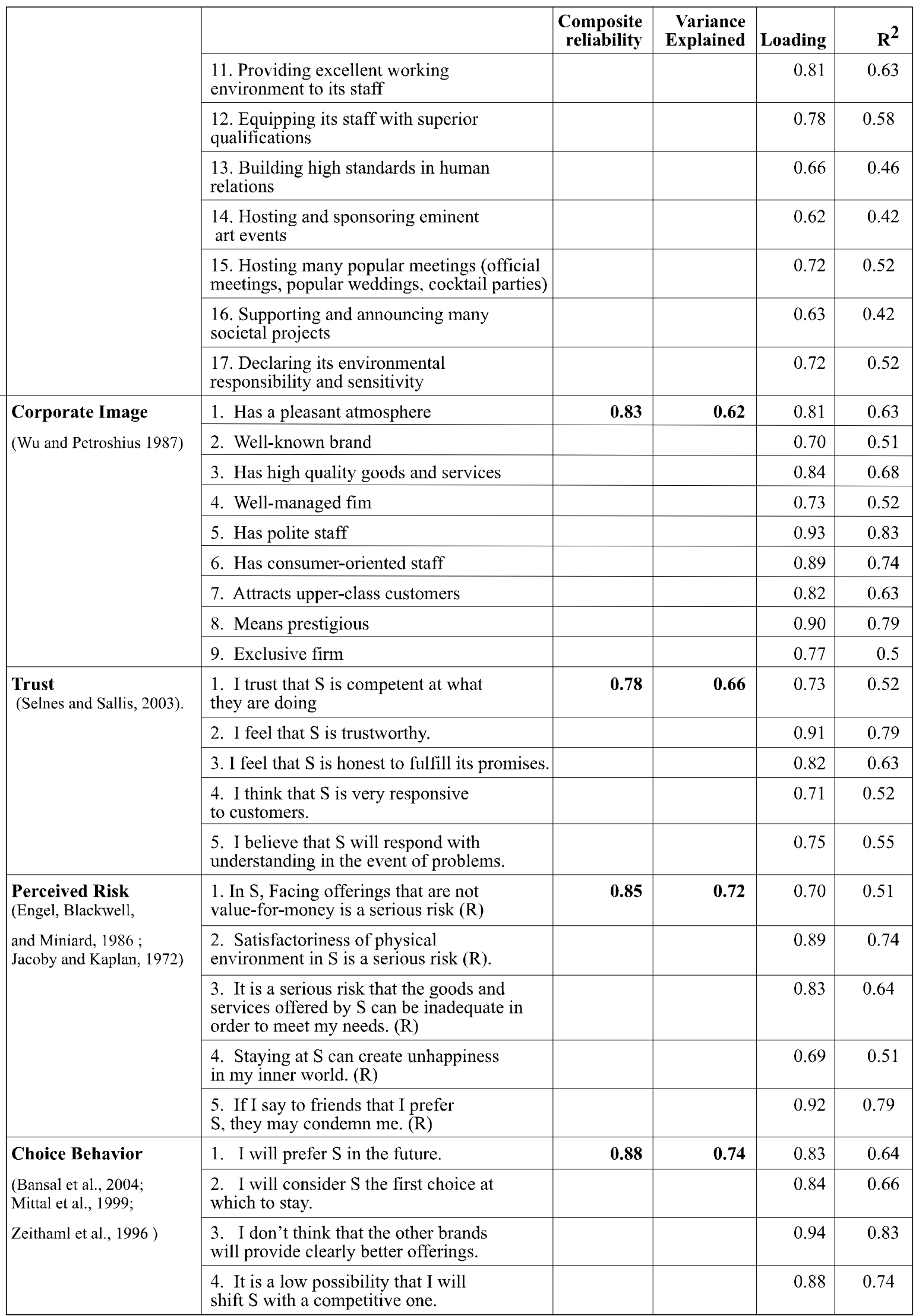




\section{Structural Model}

The estimates and hypothesis results are summarized in Table 8. Furthermore, figure 2 also provides the complete model with the path estimates. The model explained $62-74 \%$ of the variance $\left(\mathrm{R}^{2}\right.$ scores $)$. Overall, the research model accounted for $74 \%$ of the variance of choice behavior.

As seen in table 8 , all proposed relationships between the constructs of the model were supported by the statistical results. The standardized estimates of the structural parameters (i.e., RM activities corporate image and consumer trust, and corporate image consumer trust) prove that consumers' evaluations toward RM activities positively influence the view of corporate image in their minds (see table $8, \mathrm{r}: .79$ and $\mathrm{p}<0.001)$.

Similarly, RM activities to be exposed clearly determine consumer trust positively towards the firm who organized RM activities (r: .68 and $\mathrm{p}<0.001$ ). These outcomes confirm $\mathrm{H} 1$, in that positive evaluations of consumers towards RM activities of the firm lead to positive corporate image in their minds. Also, the hypothesis $\mathrm{H} 2$ was confirmed by the results, in that positive evaluations of consumers towards RM activities lead to higher level of trust towards the firm in consumer psychology. It is possible, therefore, to state that RM activities organized by firms have a direct influence on both the appearance of the firm in the marketplace, and inner evaluation processes consumers activate. Thus, RM activities of firms have a power to create doubled effect on consumers' decision making process as external and internal stimuli.

Table 8: Structural Model of RM Activities on CI, CT, PR and CB
Consumer trust is also positively influenced by corporate image, as hypothesized in $\mathrm{H} 3$ ( $\mathrm{r}$ : .42 and $\mathrm{p}$ $<0.01$ ). This confirmation for $\mathrm{H} 3$ shows that positive corporate image in the minds of consumers plays a supportive role to enhance the feeling of trust in consumer psychology. Therefore, RM activities have both direct influences on consumer trust, and indirect influences on it through corporate image.

H4 and H5 investigate the impact of corporate image and consumer trust on the factor of perceived risk. The standardized estimates of the structural parameters reveal that corporate image has a significant effect on perceived risk, but in negative direction ( $\mathrm{r}$ : - .44 and $\mathrm{p}<0.01$ ). In other words, perceived risk by consumers for a given firm is negatively influenced by corporate image in the mind of consumers. That is, the more positive corporate image consumers assume the less perceived risk they have. Also, the results confirm $\mathrm{H} 5$, in that a higher consumer trust toward a firm leads to a lower perceived risk by consumers ( $\mathrm{r}:-.76$ and $\mathrm{p}<0.001)$. Thus, perceived risk by consumers is influenced significantly by the two variables in negative direction, as hypothesized in the research model.

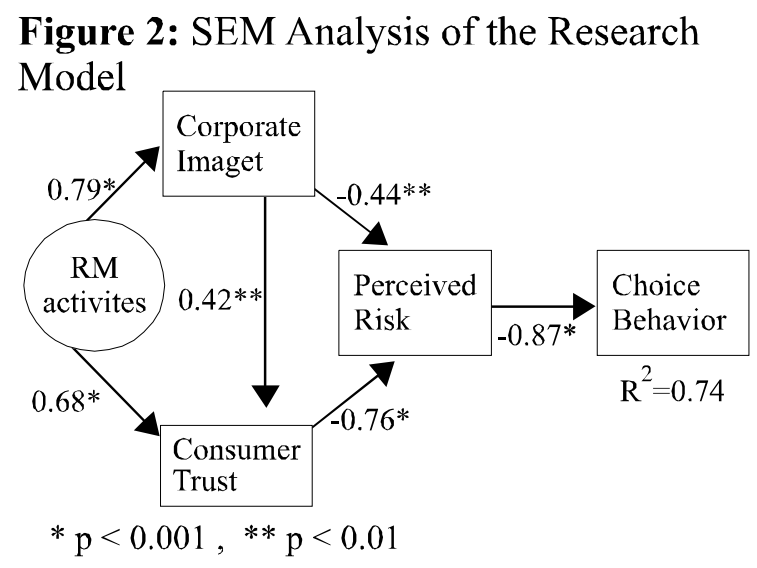

\begin{tabular}{|c|c|c|c|c|}
\hline \multicolumn{2}{|l|}{ Parameter (Paths) } & \multirow{2}{*}{$\begin{array}{r}\text { Hypothesis } \\
\text { H1 (+) }\end{array}$} & & \multirow{2}{*}{$\begin{array}{r}\text { Estimates } \\
0.793^{*}\end{array}$} \\
\hline RM Activities & Corporate Image & & & \\
\hline RM Activities & Consumer Trust & $\mathrm{H} 2(+)$ & & $0.678^{*}$ \\
\hline Corporate Image & Consumer Trust & $\mathrm{H} 3(+)$ & & $0.423 * *$ \\
\hline Corporate Image & Perceived Risk & H4 (-) & & $-0.447 * *$ \\
\hline Consumer Trust & Perceived Risk & H5 (-) & & $-0.763 *$ \\
\hline Perceived Risk & Choice Behavior & H6 (-) & & $-0.872 *$ \\
\hline \multicolumn{2}{|c|}{ Squared Multiple Correlations for Structural Equations } & & Estimates & \\
\hline \multicolumn{2}{|c|}{ Corporate Image } & & 0.71 & \\
\hline \multicolumn{2}{|l|}{ Consumer Trust } & & 0.62 & \\
\hline \multicolumn{2}{|l|}{ Perceived Risk } & & 0.66 & \\
\hline \multicolumn{2}{|l|}{ Choice Behavior } & & 0.74 & \\
\hline
\end{tabular}

$* \mathrm{p}<0.001$

$* * \mathrm{p}<0.01$ 
Comparing the values of the two coefficients, it appears that consumer trust has greater influence on perceived risk by consumers than corporate image they have.

The analyses of the hypotheses obviously point out that perceived risk by consumers is a significant determinant on their choice behavior ( $\mathrm{r}:-.87, \mathrm{p}<$ 0.001 ), in support of H6. Perceived risk seems to have a negative impact on choice behavior of consumers, just as hypothesized at the beginning of the research. Based on this test result, one can infer that higher perceived risk will result in lower choice behavior. Thus, it is possible to say that in order to increase the positive attitude toward choice of firm's offerings, perceived risk should be cut off through enhancing consumer trust based on RM activities.

Overall, all the parameters are significant in the research model. According to Chin (1998), in order coefficients to be considered meaningful they should be above the value 0.2 . In our research model all parameters were computed between $0.42-0.87$, indicating considerable impact. Moreover, all the structural relationships are in the hypothesized direction (table 8). These findings strongly support the positive relationships between RM activities and corporate image created in the minds of consumers and consumer trust in psychological structure (figure 2), negative relationships between corporate image - consumer trust and perceived risk, and then a negative relationship between perceived risk and choice behavior. These results are not only consistent with the findings of previous studies (e.g. Benjamin and Podolny, 1999; Keh and Xie, 2008) but also with our expectations of associated relationships among the constructs.

\section{CONCLUSION}

This paper aims to understand the role of RM activities on consumers' choice behaviors. Drawing on the literature for reputation management and behavioral intensions of consumers, this research study theoretically develops and empirically measures a model analyzing the effects of RM activities toward the evaluations of consumers and then choice behavior. In conclusion, choice behavior of consumers can be predicated as a dependent variable with a rate of 74 $\%$ through antecedent constructs triggered by RM activities.

Empirical results clearly reveal that perceived risk by consumers plays a determinative role in the process. Therefore, we should especially focus on how to minimize perceived risk through RM activities. It is possible to say that RM activities influence consumers' decision making process with indirect effects by enhancing corporate image and creating trust. The empirical results of this study show that perceived risk can be decreased by increasing consumer trust and positive corporate image based on RM activities of firms. Thus, if firms organize specific RM activities (i.e. making high-volume and continuous commitments to the market for superior customer satisfaction, announcing the famous people preferring the offerings of the firm, sponsoring important events in social life) strategically and systematically, this will able to function in building positive judgements resulting in lesser perceived risk and finally in more positive tendencies to prefer any given firm's offerings.

We note that the findings of this study should be assessed together with some specific limitations. First, the data required were collected from actual customers of a firm within its business atmosphere rather than in an unrelated place. However, designing a research activity in Sheraton was the result of the difficulties to reach consumers for examining the reflections of RM activities of any firm.

Second, although all hypotheses are supported, the findings of this study were generated from the customers of only one firm. This type of research should be reinforced by a variety of research outputs examining the other firms' cases.

Finally, the research model developed in this study can be expanded by other possible antecedents and consequences of reputation management (i.e., corporate identity, consumer sensitivity) to be able to produce more sophisticated understanding. 


\section{REFERENCES}

Ajzen, I., and Fishbein, M. (1980), Understanding Attitudes and Predicting Social Behavior, PrenticeHall, Englewood Cliffs, NJ,

Anderson, E., and Weitz, B. A. (1989), Determinants of continuity in conventional industrial channel dyads, Marketing Science, 8 (4), 310-323

Ba, S. and Pavlou, P.A. (2002), Evidence of the effect of trust building technology in electronic market: price premiums and buyer behavior, MIS Quarterly, 26 (3), $243-268$

Balmer, J.M.T. and Gray, E.R. (1999), Corporate identity and corporate communication: creating a strategic advantage, Corporate Communications: An International Journal, 4 (4),171-6.

Bansal, H. S., Irving, G. P., and Taylor, S. F. (2004), A three-component model of customer commitment to service providers, Journal of the Academy of Marketing Science, 32 (3), 234-250

Barich, H. and Kotler, P. (1991), A framework for marketing image management, Sloan Management Review, 32(2), 94-104

Bauer, R.A, (1960), Consumer behavior as risk taking. Dynamic marketing for a changing world, American Marketing Association, Chicago, IL

Barney, J. (1991), Firm Resources and Sustained Competitive Advantage, Journal of Management, 17 (1), 99-120.

Becker, G.S. (1990), The Economic Approach to Human Behavior, The University of Chicago Press

Benjamin, B.A. and Podolny, J.M. (1999), Status, quality and social order in California wine industry. Administrative Science Quarterly, 44 (3), 563 - 589

Blau, P. M. (1964), Exchange and Power in Social Life, John Wiley and Sons, New York, NY

Bloemer, J. and Odekerken-Schröder, G. (2007), The Psychological Antecedents of enduring customer relationships: an empirical study in a bank setting, Journal of Relationship Marketing, 6 (1), 21 - 43

Brown, T. J., Dacin, P. A., Pratt, M. G., and Whetten, D. A. (2006), Identity, intended image, construed image, and reputation: an interdisciplinary framework and suggested terminology, Journal of the Academy of Marketing Science, 34(2), 99-106

Calantone, R.J., Cavusgil, S.T. and Zhao, Y. (2002), Learning orientation, firm innovation capability, and firm performance, Industrial Marketing Management, 31(6), 515- 524
Capozzi, L. (2005), Corporate reputation: our role in sustaining and building a valuable asset. Journal of Advertising Research, 45 (3), 290 - 293

Carmeli, A. and Tishler, A. (2005), Perceived organizational reputation and organizational performance: an empirical investigation of industrial enterprises, Corporate Reputation Review, 8(1),1330.

Chen, L. and Tan, J. (2004), Technology Adaptation in E-commerce: Key Determinants of Virtual Stores Acceptance, European Management Journal, 22 (1), 74-86.

Chin, W. W. (1998), Issues and Opinion on Structural Equation Modeling. Management Information Systems Quarterly, 22 (1), vii - xvi.

Cook, K.S. and Emerson, R.M. (1978), Power, equity and commitment in exchange Networks, American Sociological Review, 43 (5), 721 - 739

Cretu, A. E., and Brodie, R. J. (2007), The influence of brand image and company reputation where manufacturers market to small firms: a customer value perspective, Industrial Marketing Management, 36(2), 230-240.

Crompton, J.L. (1979), An Assessment of the Image of Mexico as a Vacation Destination and the Influence of Geographical Location Upon That Image, Journal of Travel Research, 17(4), 18-24

Davies, G., Chun, R., da Silva, R. V. and Roper, S. (2003), Corporate Reputation and Competitiveness, Routledge, Londra, New York

Davies, G., Chun, R., da Silva, R. and Roper, S. (2002), Corporate reputation and performance in Germany, Corporate Reputation Review, 2, 115-123

Deephouse, D.L. (2000), Media reputation as a strategic resource: an integration of mass communication and resource-based theories, Journal of Management, 26 (6), $1091-1112$

Dichter, E., (1985), What's in an image?, Journal of Consumer Marketing 2(1), 75-81

Dobni, D. and Zinkhan, G.M. (1990), In Search of Brand Image: A Foundation Analysis. In Advances in Consumer Research, M. E. Goldberg, G. Gorn and R. W. Pollay, eds, Vol. 17: Provo, UT: Association for Consumer Research, 110119

Doney, P. M. and Cannon, J. P. (1997), An examination of the nature of trust in buyer-seller Relationships, Journal of Marketing, 61(2), 35-51

Dowling, G.R. and Staelin, R. (1994), A Model of 
Perceived Risk and Intended Risk-Handling Activity, The Journal of Consumer Research, 21 (1), 119-134

Dowling, G. (2006), How good corporate reputations create corporate value. Corporate Reputation Review, 9 (2), $134-143$

Engel, J.F., Blackwell, R.D. and Miniard,P.W. (1986), Consumer Behavior, Fifth Edition. Chicago: Dryden

Finn, D. (1961), The price of corporate vanity, Harvard Business Review, 39,135-143

Fombrun, C. and Shanley, M. (1990), What's in a name? Reputation building and corporate Strategy, Academy of Management Journal, 33(2), 233-258

Fombrun, C. J. (1996), Reputation: realizing value from the corporate image, Boston: Harvard Business School Press.

Fombrun, C. J. (1998), Indices of corporate reputation: an analysis of media rankings and social monitors' ranking. Corporate Reputation Review, 1 (4), 327 340

Fombrun, C. J., Gardberg, N.A., and Sever, J. M. (2000), The reputation quotient: a multi-stakeholder measure of corporate reputation. The Journal of Brand Management, 7 (4), 241 - 255

Fombrun, C.J. and van Riel,C. (2004), Fame \& Fortune, FT Prentice Hall, New York.

Fornell, C. and Larcker, D.F. (1981), Evaluating Structural Equation Models with Unobservable Variables and Measurement Error. Journal of Marketing Research, 18, 39 - 50.

Ganesan, S. (1994), Determinants of long-term orientation in buyer-seller relationships, Journal of Marketing, 58, 1-19

Garbarino, E. and Johnson, M. S. (1999), The different roles of satisfaction, trust, and commitment in customer relationships, Journal of Marketing, 63(2), 70-87

George, J. ve Jones, G. M. (1999), Organizational Behavior, 2nd ed., Longman, USA

Greatorex, Mike and Vincent Wayne Mitchell. (1994), Modeling Consumer Risk Reduction Preferences

From Perceived Loss Data. Journal of Economic Psychology, 15, 669-685.

Groenland, E.A.G. (2002), Qualitative research to validate the RQ-dimesions, Corporate Reputation Review, 4, 309 - 315

Hutton, J.G., Goodman, M.B., Alexander, J.B., and Genest, C.M. (2001), Reputation management: the new face of corporate public relations, Public Relations
Review, 27, 247-261

Jacoby, J. and Kaplan, L. B. (1972), The Components of Perceived Risk, M. Venkatesan (Ed.), Proceedings of the Third Annual Conference. Iowa City, Iowa: Association for Consumer Research, 382-393.

Keh, H. T. and Xie, Y. (2008), Corporate reputation and customer behavioral intensions: the roles of trust, identification and commitment. Industrial Marketing Management, doi: 10.1016/j.indmarman.2008.02.005

Kotler, P. (1982), Marketing for Nonprofit Organization, (2nd Edition ed.), Prentice-Hall, Englewood Cliffs, NJ.

Landon, S. and Smith, C. E. (1997), The Use of Quality and Reputation Indicators by Consumers: The Case of Bordeaux Wine, Journal of Consumer Policy, 20: 289-323

Mayer, R. C., Davis, J. H., and Schoorman, D. F. (1995), An integrative model of organizational trust, Academy of Management Review, 20(30), 709-734

McKnight, D. H., Cummings, L. L., and Chervany, N. L. (1998), Initial trust formation in new organizational relationships, Academy of Management Review, 23 (3), 473-490

Mitchell, V-W. (1999), Consumer perceived risk: conceptualisations and models. European Journal of Marketing, 33 (1/2), 163 - 195

Mittal, V., Kumar, P., and Tsiros, M. (1999), Attributelevel performance, satisfaction, and behavioral intentions over time, Journal of Marketing, 63(2), $88 ? 101$.

Moorman, C., Deshpandé, R. and Zaltman, G. (1993), Factors affecting trust in market research relationships, The Journal of Marketing, 57(1), 81-101.

Morgan, R. M., \& Hunt, S. D. (1994), The commitment-trust theory of relationship marketing, Journal of Marketing, 58, 20 ?38

Murray, K.B. and Schlacter, J.L. (1990), The impact of services versus goods on consumers' assessment of perceived risk and variability. Journal of the Academy of Marketing Science, 18 (1), 51 - 65

Pavlou, P. A. and Gefen, D. (2004), Building effective online marketplaces with institution based trust, Information Systems Research, 15 (1), 37-59

Plank, R.E., Reid,D.A. and Pullins, E.B. (1999), Perceived trust in Business to Business sales: A new measure, Journal of Personal Selling and Sales Management, 19 (3), 61-71.

Podolny, J. M. (1993), A status-based model of market 
competition, American Journal of Sociology, 98(4), $829-871$

Roberts, P. W. and Dowling, G. R. (2002), Corporate reputation and sustained superior financial performance, Strategic Management Journal, 23(12), $1077 ? 1093$

Roberts, P. W. and Dowling, G. R. (1997), The value of a firm's corporate reputation: how reputation helps attain and sustain superior profitability, Corporate Reputation Review, 1(1), 72-76

Ryan, T.A. (1970), Intentional Behavior, New York: Ronald Press.

Selnes, F. and Sallis, J. (2003), Promoting relationship learning. Journal of Marketing, 67 (3), 80-95

Simoes, C., Dibb, S. and Fisk, R.P. (2005), Managing corporate identity: an internal perspective, Journal of the Academy of Marketing Science, 33 (2), 153 - 168

Sirdeshmukh, D., Singh, J. and Sabol, B. (2002), Consumer trust, value, and loyalty in relational exchanges. Journal of Marketing, 66 (1), 15 - 37

Sultan, F. and Mooraj, H.A. (2001), Designing a trustbased E-business strategy, Market Management, 10(4), 40-45.

Taewon, S. and Amine, L.S. (2007), Defining and Managing Reputational Capital in Global Markets, The Journal of Marketing Theory and Practice, 15 (3), 205-217.

Tversky A. and Kahneman, D. (1981), The framing of decisions and the psychology of choice, Science, 211 (4481), 453-458

Tversky A. and Kahneman, D. (1986), Rational Choice and the Framing of Decisions, Journal of Business, 59 (4), $251-278$

Tversky A. and Kahneman, D. (1991), Loss aversion in riskless choice: a reference - dependent model, The Quarterly Journal of Economics, 106 (4), 1039 - 1061 Weigelt, K. and Camerer, C. (1988), Reputation and corporate strategy: a review of recent theory and applications, Strategic Management Journal, 9(5), $443 ? 454$

Weiss, A. M., Anderson, E. and MacInnis, D. J. (1999), Reputation management as a motivation for sales structure decisions, Journal of Marketing, 63(4), 74?89

Wu, B.T. and Petroshius, S.M. (1987), The halo effect in store image management. Journal of the Academy of Marketing Science, 15 (3), 44-51.
Zeithaml, V. A., Berry, L. L. and Parasuraman, A. (1996), The behavioral consequences of service quality, Journal of Marketing, 60(2), 31 ?46 